
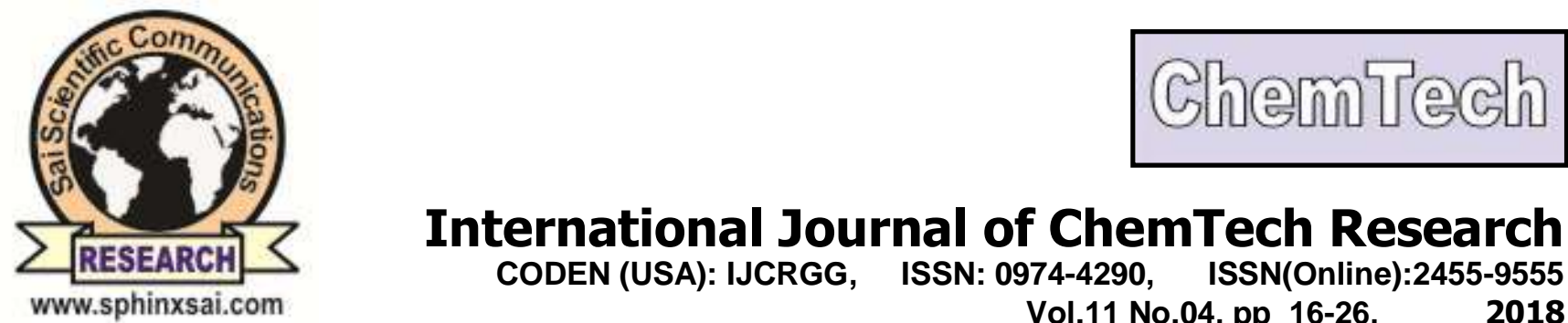

International Journal of ChemTech Research CODEN (USA): IJCRGG, ISSN: 0974-4290, ISSN(Online):2455-9555

\title{
Embedded Control of Z Source and Quasi-Z Source Based Multilevel Inverter
}

\author{
C.R.Balamurugan ${ }^{1 *}$, A.N.Abhirami ${ }^{2}$, M.Palpandian ${ }^{3}$ \\ ${ }^{1}$ Department of EEE/Karpagam College of Engineering/Coimbatore, India \\ ${ }^{2}$ Department of EEE/ Indiragandhi College of engineering and technology for \\ women/Chengalpattu, India \\ ${ }^{3}$ Department of EEE/ Sethu Institute of Technology/Kariappati, India
}

\begin{abstract}
In this paper an embedded based Z source and Quasi Z-source based multilevel inverter is proposed. The proposed system has the Z-source network that is used to couples the inverter main circuit to the power source. The presence of $Z$-source network can able to buck and boost the given voltage. Quasi Z-source inverter has advantages over the classical Zsource inverter that it has continuous input current drawn from the source and reduces the voltage stress across the capacitors. Limitations of voltage source inverter (VSI) and current source inverter (CSI) can overcome by Z-source inverter (ZSI). Switching strategy of multilevel inverter is controlled by embedded controller. In this controller coding is developed using switching table. Simulation model of Z-source and Quasi Z-source based multilevel inverter with embedded controller is developed using MATLAB/Simulink. The performance parameters such as RMS, THD, DC component and output result of the inverter with R load have been analyzed for various inductance $(\mathrm{L})$ and capacitance $(\mathrm{C})$ values.

Keywords : Z-source Inverter; Quasi Z-Source Inverter; Multilevel Inverter; Embedded Controller; THD; RMS.
\end{abstract}

\section{Introduction}

Z-source inverter utilizes impedance network between DC source and inverter circuitry to achieve boost operation. Z source inverter unlike traditional inverters can utilize shoot through state to boost the DC voltage. Quasi Z-source inverter has continuous input current and reduces the voltage stress across the capacitors. Impedance source based multilevel inverter eliminates the limitation of both voltage source inverter and current source inverter. Embedded switching scheme is used to trigger the multilevel inverter. In embedded controller, coding is developed in order to generate the pulses. Coding is composed by switching states. Multilevel inverter is a power electronic device. It is used to synthesize a desired AC output voltage from several DC sources. The attractive features of multilevel inverter can be summarized as follows.

- It draws input current with low distortion.

- It not only can generate the output voltage with very low distortion but also can reduce the $\mathrm{dv} / \mathrm{dt}$ stresses and therefore reduces the Electromagnetic Compatibility (EMC) problems.

International Journal of ChemTech Research, 2018,11(04): 16-26.

DOI : http://dx.doi.org/10.20902/IJCTR.2018.110402 
- Multilevel inverter has a unique structure that allows reaching high voltage and power levels without the use of transformers.

Cascaded multilevel inverter is developed for electric utility applications [1]. Survey of different topologies, Control strategies and modulation techniques of cascaded multilevel inverter is proposed [2]. Several modulation techniques for three level quasi Z-source inverter are proposed [3]. The performance of single phase Z-source inverter is analyzed by using MATLAB/simulink [4]. The switching function of proposed MLI topology is controlled by embedded controller and performance of MLI is observed [5]. The proposed MLI topology is controlled by embedded controller and its give high quality output nearer to the sinusoidal waves [6]. The proposed controller implements a discrete time model of the quasi Z-source inverter to predict the behavior of the circuit variables for each switching state [7]. Finite control set-model predictive algorithm is proposed for quasi Z-source inverter [8]. Different topology of cascaded multilevel inverter and its control strategies are proposed [9]. New circuit topology of a three phase half-bridge multilevel inverter is proposed [10].

\section{Z-Source Inverter}

Z-source inverter can boost the given input DC voltage without step up transformer or DC-DC boost converter. The general structure of Z-source inverter shown in fig. 1 it has two inductors and two capacitors. It form a unique impedance network to couples the main circuit to the power source.

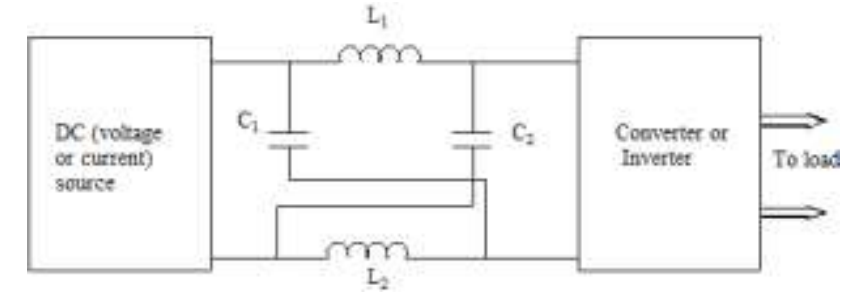

Fig. 1. General Structure of Z-Source Inverter

$V_{\text {OUT }}=B M \frac{V_{d c}}{2}$

Where

$V_{\text {OUT }}=$ Maximum sinusoidal inverter output voltage

$\mathrm{B}=$ Boost factor

$\mathrm{M}=$ Modulation index

$V_{d c} \quad=$ DC input voltage

$V_{\text {OUT }}=G \frac{V_{d c}}{2}$

$\mathrm{G}=\mathrm{BM}$

$\mathrm{G}=$ Inverter gain

a) Shoot Through State

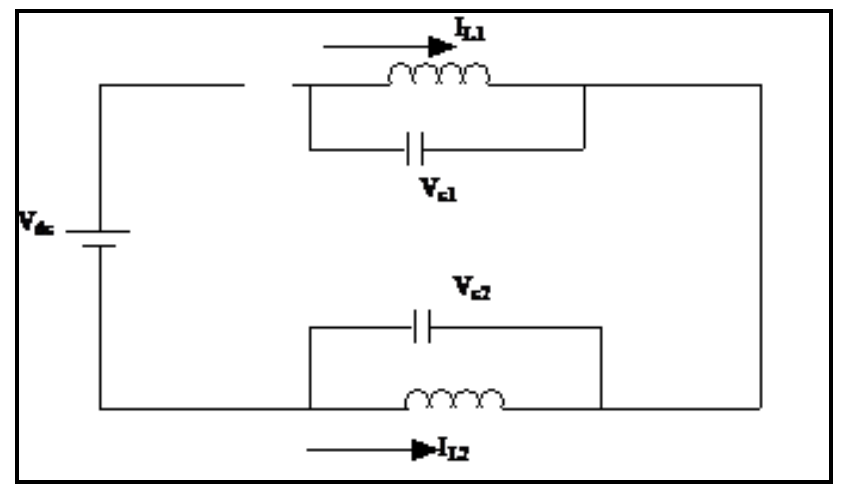

Fig. 2. Shoot Through State 
Fig.2 shows the shoot through switching state of the inverter. During shoot through switching state of the $\mathrm{Z}$ source inverter where two switches of one leg or two legs or all three legs are turned on simultaneously known as shoot through state. It gives boosting capability to the inverter. During shoot through state energy is transferred from capacitor to inductor. Diode connected in series with DC source is reverse biased at this state.

Voltage across the inductors is

$$
V_{L 1}=V_{C 1}, V_{L 2}=V_{C 2}
$$

\section{b) Non Shoot Through State}

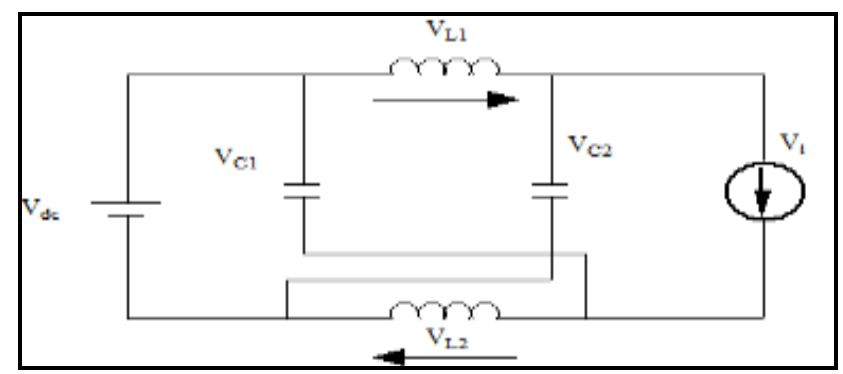

Fig. 3. Non Shoot Through State.

Diode $\mathrm{D}$ at the input side conducts during this mode. The capacitors in the impedance network being charged and inductors act as an additional current source. So the inverter side voltage is boosted. Voltage across the inductor is

$V_{L}=V_{d c}-V_{c}$

Voltage across inverter bridge during non shoot through state is

$V_{i}=V_{C}-V_{L}=2 V_{c}-V_{d c}$

\section{Quasi Z Source Inverter}

Quasi Z-source inverter has the ability to buck or boost the input voltage which is connected between the source and inverter main circuit. The input current of Z-source inverter is discontinuous because the diode connected in series disconnects the Z-network from the source which is undesirable for some sources. To overcome this drawback, quasi Z-source inverter was proposed.

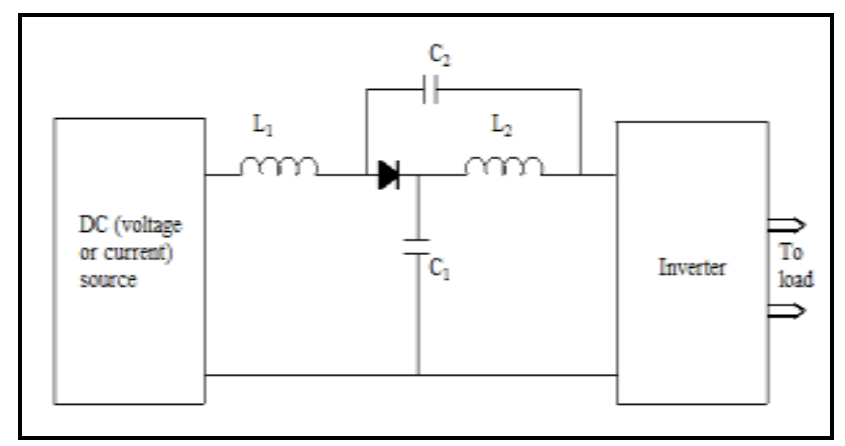

Fig. 4. Quasi Z-Source Inverter 


\section{a) Shoot Through State}

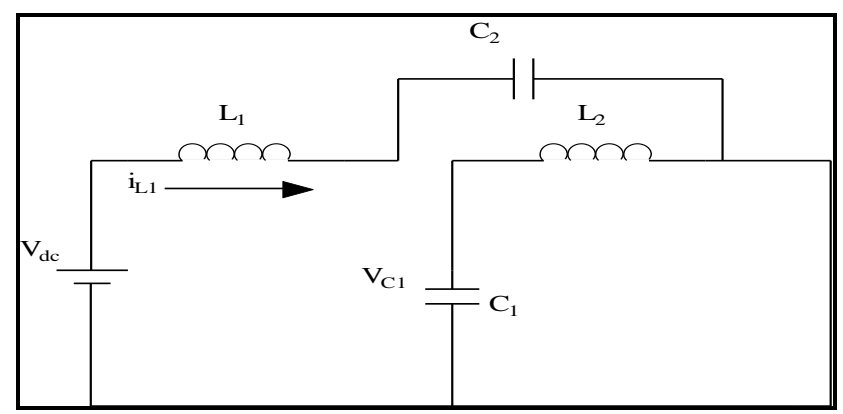

Fig. 5. Shoot Through State.

During this state the diode is reverse biased and the obtainable inductor voltage and capacitor current represented in the following equation.

$$
\begin{aligned}
& L_{1} \frac{d i_{L 1}}{d t}=V_{C 1}+R_{\text {ind }} i_{L 1} \\
& C_{1} \frac{d V_{C 1}}{d t}=-i_{L 1}
\end{aligned}
$$

Where $\mathrm{L} 1$ and $\mathrm{C} 1$ are the inductance and capacitance, Rind is the internal resistance of inductor.

\section{b) Non Shoot Through State}

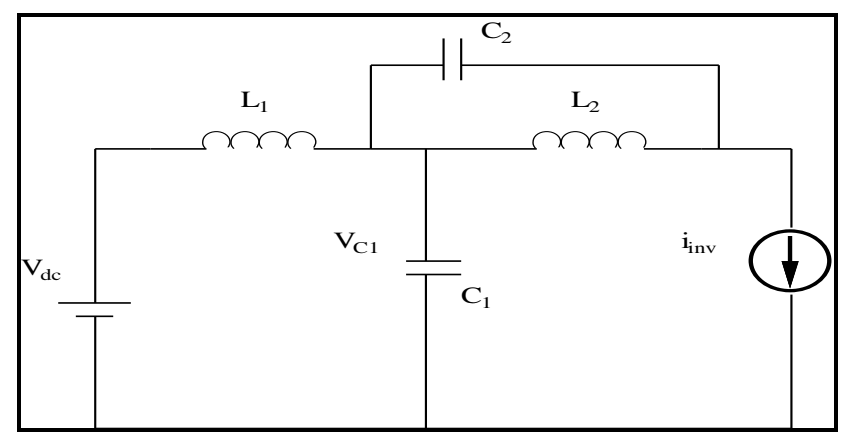

Fig. 6. Non Shoot Through State

Fig.6 shows the non shoot through state case of quasi Z-source inverter. During this state the diode is forward biased. Following equations express the inductor voltage and capacitor current.

$L_{1} \frac{d i_{L 1}}{d t}=V_{C 1}-V_{d c}-R_{\text {ind }} i_{L 1}$

$C_{1} \frac{d V_{C 1}}{d t}=i_{L 1}-i_{i n v}$

$\mathrm{V}_{\mathrm{dc}}$ is the dc input voltage; inv is the inverter output current.

\section{Embedded Controlled Multievel Inverter}

Due to reduced number of components and its simplicity cascaded multilevel inverter is chosen than other topologies. Fewer or more H-bridge connected in series to decrease or increase voltage and power levels. In order to obtain a five level output two H-bridge is connected in series. Switching scheme of this multilevel inverter is controlled by embedded controller. In this embedded controller, coding is developed by using switching states that is developed to generate the pulses. 
The coding is made by using MATLAB software.

function $\mathrm{y}=\mathrm{fcn}(\mathrm{u})$

$\mathrm{a}=\bmod (\mathrm{u} * 1000,10)$;

$\mathrm{b}=\bmod \left(\mathrm{u}^{*} 1000,20\right)$;

if $a<1.2 \% 0$

$\mathrm{p} 5=1$;

p6=0;

$\mathrm{p} 7=1$;

$\mathrm{p} 8=0$

$\mathrm{p} 9=0$;

p10=1;

p11 $=0$;

p12=1;

else if $a<3.1 \% 3$

$\mathrm{p} 5=1$;

p6=1;

p7 $=0$;

$\mathrm{p} 8=0$;

$\mathrm{p} 9=0$;

p10=1;

p11=0;

p12=1;

else if $a<7.2 \% 4$

$\mathrm{p} 5=1$;

p6=1;

p7 $=0$;

p8 $=0$;

p9=1;

p10 $=1$;

p11 $=0$;

$\mathrm{p} 12=0$;

else if a $<9.1 \% 5$

$\mathrm{p} 1=1$;

p2=1;

p3 $=0$;

$\mathrm{p} 4=0$;

p5=0;

p6=1;

p7 $=0$;

$\mathrm{p} 8=1$;

else \%0

p5=1;

p6 $=0$;

p7 $=1$;

$\mathrm{p} 8=0$;

$\mathrm{p} 9=0$;

p10=1;

p11 $=0$;

p12=1;

end

if $b<10$

$\mathrm{y}=[\mathrm{p} 5, \mathrm{p} 6, \mathrm{p} 7, \mathrm{p} 8, \mathrm{p} 9, \mathrm{p} 10, \mathrm{p} 11, \mathrm{p} 12]$;

else

$\mathrm{y}=[\mathrm{p} 7, \mathrm{p} 8, \mathrm{p} 5, \mathrm{p} 6, \mathrm{p} 11, \mathrm{p} 12, \mathrm{p} 9, \mathrm{p} 10]$;

end 


\section{Proposed Topology}

In this paper propose a Z-source and quasi Z-source based multilevel inverter to overcome the limitations of individual convention Z-source inverter and multilevel inverter. It combines the features of both Z-source inverter and multilevel inverter. It can able to buck and boost the given input voltage. Presence of quasi Z-source inverter provides continuous input current. The performance of proposed topologies is analyzed by simulation by using MATLAB software.

\section{a) Z-Source Multilevel Inverter based on Embedded Controller}

Z-source multilevel inverter is implemented in fig. 7 it consist of an impedance network and multilevel inverter. To achieve a five level output across multilevel inverter two $\mathrm{H}$-bridge are connected in series and the load is assumed to be R load. Each impedance network has two split inductors and two capacitors. The proposed topology has an extra switching state that is known as shoot through state. By proper adjustment of shoot through time period of Z-source multilevel inverter the input voltage can buck or boost. In this Z-source multilevel inverter the switching devices are controlled by using embedded controller. Z-source inverter as compared to traditional inverter is less costly, more efficient and reliable.

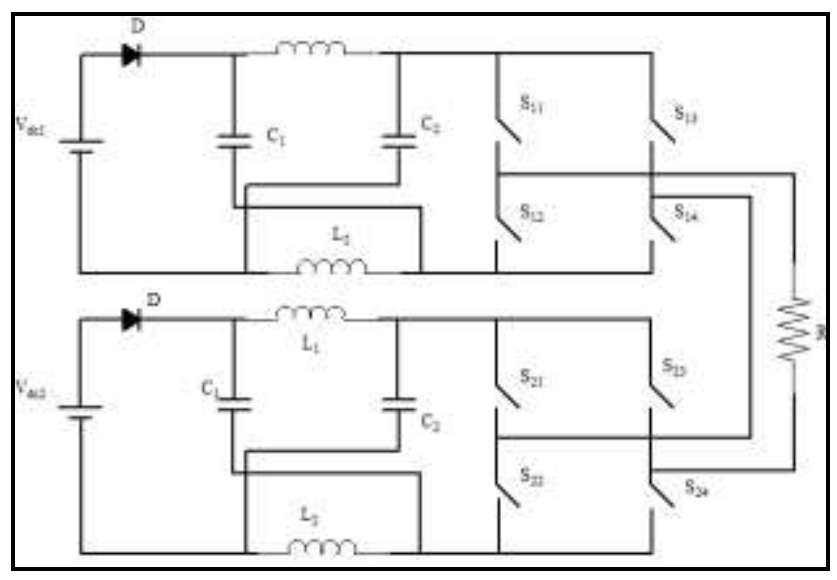

Fig. 7. Z-Source Multilevel Inverter based on Embedded Controller

By proper adjustment of shoot through time period of Z-source multilevel inverter the input voltage can buck or boost. In this Z-source multilevel inverter the switching devices are controlled by using embedded controller. Z-source inverter as compared to traditional inverter is less costly, more efficient and reliable.

\section{b) Quasi Z-Source Multilevel Inverter based on Embedded Controller}

Fig. 8 shows the quasi Z-source inverter based on embedded controller. Impedance network connects the DC source and main circuit. The load is assumed to be $\mathrm{R}$ as same as Z-source multilevel inverter. In quasi Zsource inverter when the diode is reverse biased the inverter perform a shoot through operation and during non shoot through state the diode getting reverse biased. Switching scheme of the multilevel inverter is controlled by embedded controller in order to obtain a five level output.

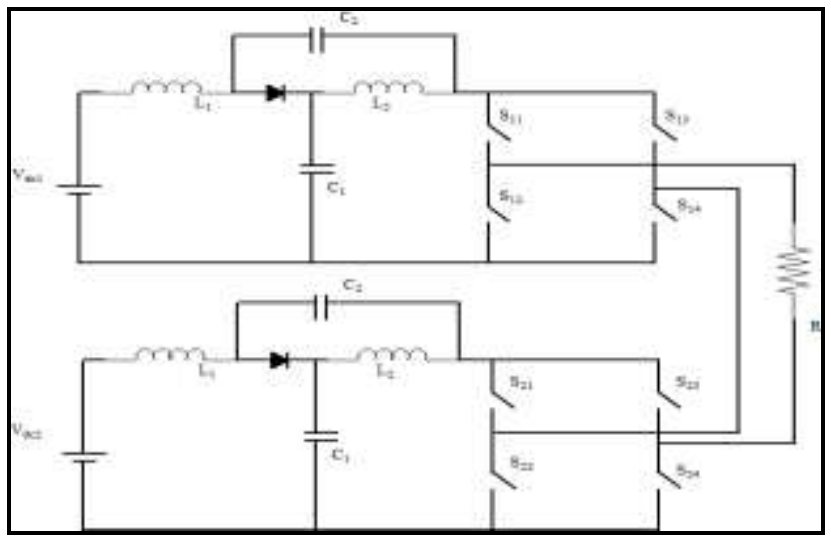

Fig. 8. Quasi Z-Source Multilevel Inverter based on Embedded Controller 


\section{Simulation Results}

MATLAB software is used to simulate the proposed Z-source and quasi Z-source based multilevel inverter. Presents RMS output voltage, THD and DC component is analyzed by using FFT analysis.. Performance of proposed topologies is analyzed for four various inductance (L) and Capacitance (C) values.

Table 1 Chosen L And C Values

\begin{tabular}{|l|l|l|}
\hline S.No & Inductance(H) & Capacitance(F) \\
\hline 1 & $3 \mathrm{mH}$ & $4700 \mu \mathrm{F}$ \\
\hline 2 & $3 \mathrm{mH}$ & $470 \mu \mathrm{F}$ \\
\hline 3 & $160 \mu \mathrm{H}$ & $1000 \mu \mathrm{F}$ \\
\hline 4 & $250 \mu \mathrm{H}$ & $500 \mu \mathrm{F}$ \\
\hline
\end{tabular}

A value of $L$ and $C$ in impedance network is varied as per chosen $L$ and $C$ values. Chosen $L$ and $C$ value is represented in the table 1. Fig.9 displays the output voltage across ZSMLI without filter based on embedded controller for $\mathrm{L}=250 \mu \mathrm{H}$ and $\mathrm{C}=500 \mu \mathrm{F}$. Harmonic spectrum of ZSMLI based on embedded controller is represented in fig. 10 .

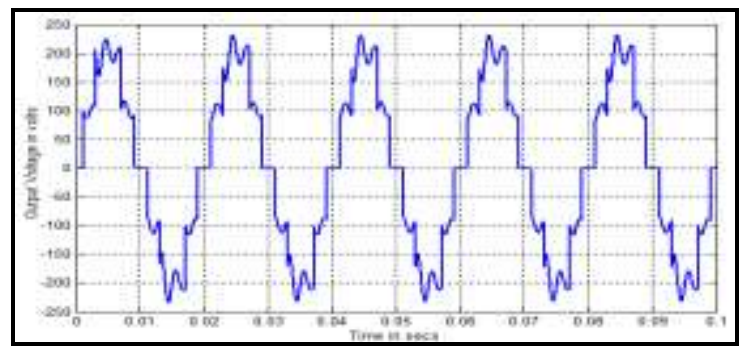

Fig.9. Output Voltage of ZSMLI without Filter based on Embedded Controller

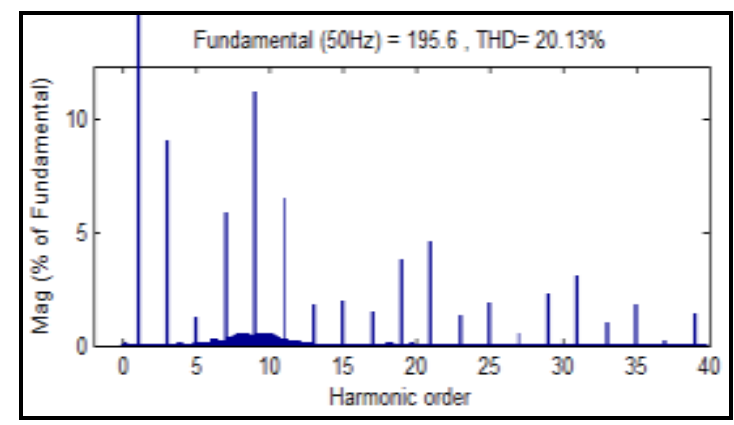

Fig. 10. Harmonic Spectrum of ZSMLI based on Embedded Controller without Filter

Fig.11 and 12 represents the output voltage and harmonic spectrum of Z-source multilevel inverter with filter arrangement based on embedded controller. $\mathrm{LC}$ filter value is assumed to be $\mathrm{L}=3 \mathrm{mH}$ and $\mathrm{C}=4700 \mu \mathrm{F}$.

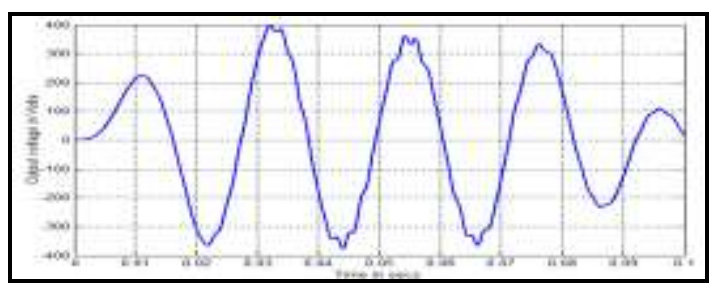

Fig.11. Output Voltage of ZSMLI with Filter based on Embedded Controller 


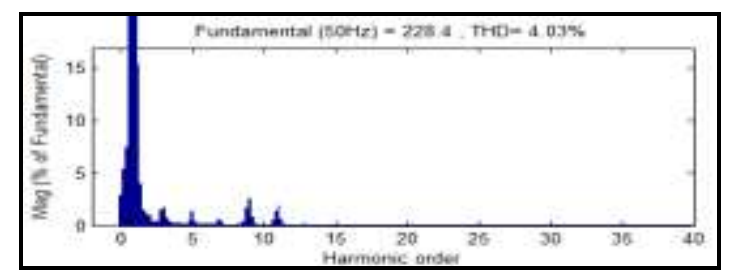

Fig.12. Harmonic Spectrum of ZSMLI with Filter based on Embedded Controller

Output voltage of quasi Z-source multilevel inverter without filter based on embedded controller is represented in the fig. 13 .

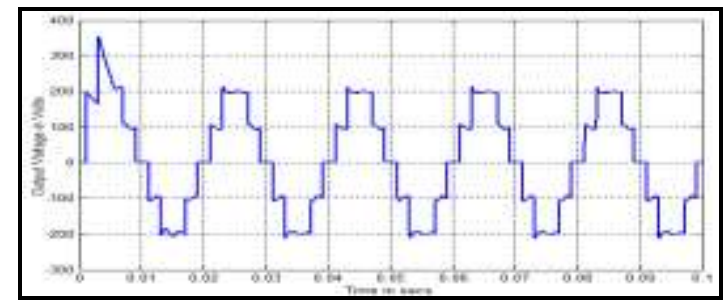

Fig.13. Output Voltage of Quasi Z-source MLI without Filter based on Embedded Controller

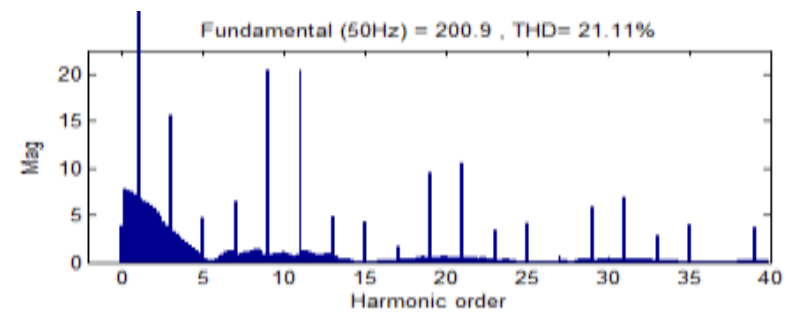

Fig.14. Harmonic Spectrum of Quasi Z-source MLI without Filter based on Embedded Controller

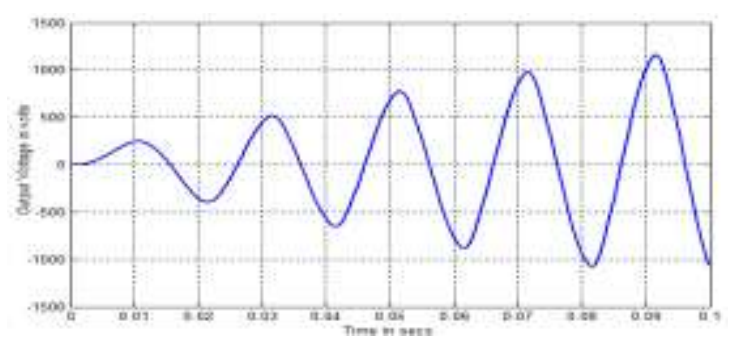

Fig.15. Output Voltage of Quasi Z-source MLI with Filter based on Embedded Controller

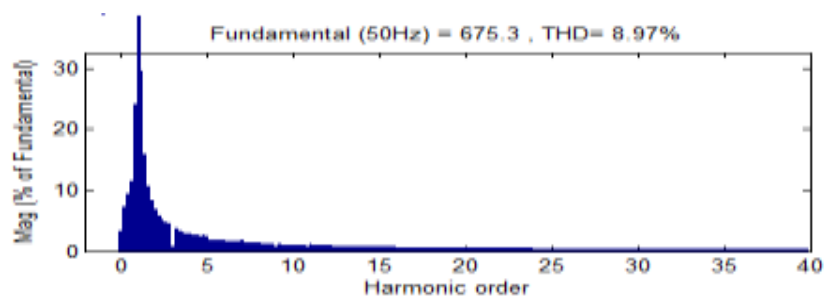

Fig.16. Harmonic Spectrum of Quasi Z-source MLI with Filter based on Embedded Controller

Output voltage and harmonic spectrum of quasi Z-source MLI with filter arrangement is shown in the above figures.

\section{a) Measurement across MLI}

In this paper five level cascaded multilevel inverter is proposed to obtain a high quality output nearer to sinusoidal waves. The switching strategy of proposed MLI is controlled by embedded controller. For various 
impedance network values, the performance parameters of proposed topologies are measured. Measurement across MLI can obtain from FFT analysis. It measures the RMS output voltage and Present THD in the output waveform with and without filter conditions. Table 2 and table 3 represent the measurement across MLI without filter and with filter arrangement. It displays the RMS output voltage and THD in the output waveform by FFT analysis.

Table 2 Measurement Across MLI Without Filter

\begin{tabular}{|l|l|l|l|l|}
\hline L and C values & \multicolumn{2}{|l|}{$\begin{array}{l}\text { Z-source MLI } \\
\text { based on } \\
\text { embedded } \\
\text { controller }\end{array}$} & \multicolumn{2}{l|}{$\begin{array}{l}\text { Quasi Z-source MLI } \\
\text { based on embedded } \\
\text { controller }\end{array}$} \\
\cline { 2 - 5 } & $\begin{array}{l}\text { RMS } \\
(\mathbf{V})\end{array}$ & $\begin{array}{l}\text { THD } \\
(\boldsymbol{\%})\end{array}$ & RMS (V) & $\begin{array}{l}\text { THD } \\
(\boldsymbol{\%})\end{array}$ \\
\hline $\mathrm{L}=3 \mathrm{mH}, \mathrm{C}=4700 \mu \mathrm{F}$ & 137.5 & 21.11 & 169.3 & $23.65 \%$ \\
\hline $\mathrm{L}=3 \mathrm{mH}, \mathrm{C}=470 \mu \mathrm{F}$ & 112.9 & 45.20 & 136.4 & $24.78 \%$ \\
\hline $\mathrm{L}=250 \mu \mathrm{H}, \mathrm{C}=500 \mu \mathrm{F}$ & 138.3 & 20.13 & 142.1 & $21.11 \%$ \\
\hline $\mathrm{L}=160 \mu \mathrm{H}, \mathrm{C}=1000 \mu \mathrm{F}$ & 134.8 & 23.79 & 146.4 & $20.59 \%$ \\
\hline
\end{tabular}

Table 3 Measurement Across MLI With Filter

\begin{tabular}{|l|l|l|l|l|}
\hline L and C values & \multicolumn{2}{|l|}{$\begin{array}{l}\text { Z-source MLI } \\
\text { based on } \\
\text { embedded } \\
\text { controller with } \\
\text { filter }\end{array}$} & \multicolumn{2}{l|}{$\begin{array}{l}\text { Quasi Z-source } \\
\text { MLI based on } \\
\text { embedded } \\
\text { controller with } \\
\text { filter }\end{array}$} \\
\cline { 2 - 5 } & $\begin{array}{l}\text { RMS } \\
(\mathbf{V})\end{array}$ & $\begin{array}{l}\text { THD } \\
(\boldsymbol{\%})\end{array}$ & $\begin{array}{l}\text { RMS } \\
(\mathbf{V})\end{array}$ & $\begin{array}{l}\text { THD } \\
(\boldsymbol{\%})\end{array}$ \\
\hline $\mathrm{L}=3 \mathrm{mH}, \mathrm{C}=4700 \mu \mathrm{F}$ & 332.6 & $8.66 \%$ & 297.8 & $10.44 \%$ \\
\hline $\mathrm{L}=3 \mathrm{mH}, \mathrm{C}=470 \mu \mathrm{F}$ & 28.74 & $28.24 \%$ & 193.2 & $14.10 \%$ \\
\hline $\mathrm{L}=250 \mu \mathrm{H}, \mathrm{C}=500 \mu \mathrm{F}$ & 161.4 & $4.02 \%$ & 477.5 & $8.97 \%$ \\
\hline $\mathrm{L}=160 \mu \mathrm{H}, \mathrm{C}=1000 \mu \mathrm{F}$ & 125.5 & $8.42 \%$ & 490.5 & $7.36 \%$ \\
\hline
\end{tabular}

\section{b) Harmonic Contents in the Proposed Topologies}

The harmonic present in the inverter system can lead to some disadvantages. Presence of harmonic currents will lead to excessive current heating. Presence of harmonic contents in the output waveform observed by FFT analysis. Odd and Even harmonic contents in the output have been analyzed in this work. Table 4 and 5 shows the odd and even harmonic contents in the proposed Z-source and quasi Z-source MLI based on embedded controller. Total harmonic distortion measures the closeness in the shape between a waveform and its fundamental component. The harmonic component whose frequency is close to fundamental and the amplitude is greater than or equal to $3 \%$ of fundamental value is knows as lower order harmonics.

$$
T H D=\frac{1}{V_{01}}\left[\sum_{n=2,3 \ldots}^{\infty}\left(V_{0 n}\right)^{2}\right]^{\frac{1}{2}}
$$

Harmonic factor indicate each harmonic contribution to harmonic distortion and its used to check dominate harmonics in the output.

$$
H F_{n}=\frac{V_{n}}{V_{1}}
$$


Table 4 Odd Harmonic Contents

\begin{tabular}{|l|c|c|c|c|}
\hline \multirow{2}{*}{$\begin{array}{l}\text { Harmonic } \\
\text { Order }\end{array}$} & \multicolumn{2}{|c|}{$\begin{array}{c}\text { Z-Source MLI based on Embedded } \\
\text { Controller }\end{array}$} & \multicolumn{2}{|c|}{$\begin{array}{c}\text { Quasi Z-Source based on Embedded } \\
\text { Controller }\end{array}$} \\
\cline { 2 - 5 } & $\begin{array}{c}\text { Without } \\
\text { Filter }\end{array}$ & $\begin{array}{c}\text { With } \\
\text { Filter }\end{array}$ & $\begin{array}{c}\text { Without } \\
\text { Filter }\end{array}$ & $\begin{array}{c}\text { With } \\
\text { Filter }\end{array}$ \\
\hline 1 & $100 \%$ & $100 \%$ & $100 \%$ & $100 \%$ \\
\hline 3 & $9.05 \%$ & $1.67 \%$ & $7.76 \%$ & $0.78 \%$ \\
\hline 5 & $1.25 \%$ & $1.37 \%$ & $2.36 \%$ & $2.45 \%$ \\
\hline 7 & $5.90 \%$ & $0.40 \%$ & $3.24 \%$ & $1.76 \%$ \\
\hline 9 & $11.27 \%$ & $2.61 \%$ & $10.18 \%$ & $0.81 \%$ \\
\hline 11 & $6.52 \%$ & $1.89 \%$ & $10.21 \%$ & $1.17 \%$ \\
\hline 13 & $1.76 \%$ & $0.07 \%$ & $2.45 \%$ & $0.79 \%$ \\
\hline 15 & $1.99 \%$ & $0.07 \%$ & $2.14 \%$ & $0.69 \%$ \\
\hline 17 & $1.45 \%$ & $0.03 \%$ & $0.82 \%$ & $0.58 \%$ \\
\hline 19 & $3.82 \%$ & $0.08 \%$ & $4.72 \%$ & $0.52 \%$ \\
\hline 21 & $4.57 \%$ & $0.05 \%$ & $5.29 \%$ & $0.47 \%$ \\
\hline 23 & $1.29 \%$ & $0.02 \%$ & $1.70 \%$ & $0.44 \%$ \\
\hline 35 & $1.87 \%$ & $0.02 \%$ & $2.07 \%$ & $0.40 \%$ \\
\hline 27 & $0.52 \%$ & $0.02 \%$ & $0.32 \%$ & $0.37 \%$ \\
\hline 29 & $2.26 \%$ & $0.02 \%$ & $2.90 \%$ & $0.35 \%$ \\
\hline 31 & $3.38 \%$ & $0.02 \%$ & $3.42 \%$ & $0.32 \%$ \\
\hline 33 & $1.01 \%$ & $0.01 \%$ & $1.39 \%$ & $0.31 \%$ \\
\hline 35 & $1.81 \%$ & $0.02 \%$ & $1.97 \%$ & $0.29 \%$ \\
\hline 37 & $0.19 \%$ & $0.01 \%$ & $0.07 \%$ & $0.27 \%$ \\
\hline 39 & $1.41 \%$ & $0.02 \%$ & $1.83 \%$ & $0.26 \%$ \\
\hline
\end{tabular}

Table 5 Even Harmonic Contents

\begin{tabular}{|l|c|c|c|c|}
\hline \multirow{2}{*}{$\begin{array}{l}\text { Harmonic } \\
\text { Order }\end{array}$} & \multicolumn{2}{|c|}{$\begin{array}{c}\text { Z-Source MLI based on Embedded } \\
\text { Controller }\end{array}$} & \multicolumn{2}{c|}{$\begin{array}{c}\text { Quasi Z-Source based on Embedded } \\
\text { Controller }\end{array}$} \\
\cline { 2 - 5 } & $\begin{array}{c}\text { Without } \\
\text { Filter }\end{array}$ & $\begin{array}{c}\text { With } \\
\text { Filter }\end{array}$ & $\begin{array}{c}\text { Without } \\
\text { Filter }\end{array}$ & $\begin{array}{c}\text { With } \\
\text { Filter }\end{array}$ \\
\hline 2 & $0.05 \%$ & $0.96 \%$ & $2.85 \%$ & $6.84 \%$ \\
\hline 4 & $0.11 \%$ & $0.23 \%$ & $1.06 \%$ & $2.76 \%$ \\
\hline 6 & $0.30 \%$ & $0.12 \%$ & $0.29 \%$ & $1.69 \%$ \\
\hline 8 & $0.56 \%$ & $0.09 \%$ & $0.64 \%$ & $1.28 \%$ \\
\hline 10 & $0.54 \%$ & $0.06 \%$ & $0.53 \%$ & $0.97 \%$ \\
\hline 12 & $0.20 \%$ & $0.07 \%$ & $0.40 \%$ & $0.86 \%$ \\
\hline 14 & $0.05 \%$ & $0.04 \%$ & $0.17 \%$ & $0.72 \%$ \\
\hline 16 & $0.06 \%$ & $0.03 \%$ & $0.10 \%$ & $0.63 \%$ \\
\hline 18 & $0.09 \%$ & $0.03 \%$ & $0.18 \%$ & $0.56 \%$ \\
\hline 20 & $0.07 \%$ & $0.02 \%$ & $0.29 \%$ & $0.50 \%$ \\
\hline 22 & $0.08 \%$ & $0.02 \%$ & $0.21 \%$ & $0.46 \%$ \\
\hline 24 & $0.04 \%$ & $0.02 \%$ & $0.14 \%$ & $0.42 \%$ \\
\hline 26 & $0.02 \%$ & $0.02 \%$ & $0.04 \%$ & $0.39 \%$ \\
\hline 28 & $0.04 \%$ & $0.02 \%$ & $0.11 \%$ & $0.36 \%$ \\
\hline 30 & $0.03 \%$ & $0.02 \%$ & $0.19 \%$ & $0.34 \%$ \\
\hline 32 & $0.05 \%$ & $0.02 \%$ & $0.16 \%$ & $0.31 \%$ \\
\hline 34 & $0.03 \%$ & $0.01 \%$ & $0.11 \%$ & $0.30 \%$ \\
\hline 36 & $0.02 \%$ & $0.01 \%$ & $0.03 \%$ & $0.28 \%$ \\
\hline 38 & $0.03 \%$ & $0.01 \%$ & $0.08 \%$ & $0.26 \%$ \\
\hline 40 & $0.02 \%$ & $0.01 \%$ & $0.13 \%$ & $0.25 \%$ \\
\hline
\end{tabular}




\section{Conclusions}

In this paper, the performance of Z-source multilevel inverter and quasi Z-source multilevel inverter based on embedded controller is analyzed by MATLAB/SIMULINK. The performance parameters RMS output voltage and THD in proposed topologies is measured by changing chosen impedance network values. As per voltage concern higher RMS value is obtained in quasi Z-source multilevel inverter as compared to Z-source multilevel inverter at with and without filter condition. In Z-source and quasi Z-source multilevel inverter present THD is reduced up to $4.02 \%$ and $8.97 \%$ by choosing $\mathrm{L}=250 \mu \mathrm{H}$ and $\mathrm{C}=500 \mu \mathrm{F}$ for impedance network. From FFT analysis the order of harmonics 3, 7, 9, 11, 19, 21 and 31 are dominant in embedded controller based $\mathrm{Z}$-source and quasi Z-source based multilevel inverter. In quasi Z-source multilevel inverter with filter arrangement, the order of harmonic 2 is dominant.

\section{References}

1. Peng Fang-Zen, Qian Zhao-Ming. Application of Cascaded Multilevel Inverters, Journal of Zhejiang University Science, 2003, 4, 6; 658-665.

2. Mariusz Malinowski, K.GopaKumar, Jose Rodriguez and Marcelo A.Perez, A Survey on Cascaded Multilevel Inverters, IEEE Transactions on Industrial Electronics, 2010, 57, 7; 2197-2206.

3. Carlos Roncero-Clemente, Enrique Romero-Cadaval, Oleksandar Husev, Ditri Vinnikov, Simulation Study of Different Modulation Techniques for Three- Level Quasi Z-Source Inverter, Electrical Control and Communication Engineering, 2012, 11-17.

4. Thanasekaran R, Senrayan K, Anand Kumar T and Ponmanikandan P, A Novel Single Z-Source based Multilevel Inverter for Renewable Energy Sources, Conference on Electrical, Electronics and Computer Science Engineering, 2012.

5. Dastagiri Reddy B, Anish N.K, Selvan M.P, Moorthi S, Embedded Control of n-level DC-DC-AC Inverter, IEEE Transaction on Power Electronics, 2013, 1-9.

6. Sivasankari, S, Balamurugan. C.R, Embedded Controller based Multilevel Inverter Topologies, Electrical and Electronics Engineering, An Internation Journal, 2014, 3, 6; 81-89.

7. Mostafa Mosa, Robert S. Balog and Haitham Abu-Rub, High Performance Predictive Control of Quasi Impedance Source Inverter, IEEE Transaction on Industrial Electronics, 2015.

8. Abualkasim Bakeer, Mohamed A. Ismeil and Mohamed Orabi, A Powerful Finite Control Set-Model Predictive Control Algorithm for Quasi Z-Source Inverter, IEEE Transaction on Industrial Informatics, 2016, 1-10.

9. Charles Ikechukwu Odeh, Emeka S. Obe and Olorunfemi Ojo, Topology for Cascaded Multilevel Inverter: IET Power Electronics, 2016, 1-9.

10. Md Mubashwar Hasan, A, Abu-Siada and Md. Rabiul Islam, Design and Implementation of a Novel Three-Phase Cascaded Half-Bridge Inverter, IET Power Electronics, 2016, 9, 8;1741-1752 